\title{
THE ANALYSES OF GRAMMATICAL ASPECT OF NUMBER \& GENDER FROM ENGLISH INTO INDONESIAN NOVEL TRANSLATED BY SILAMURTI NUGROHO
}

\author{
Haryani ${ }^{1 *}$, Yusi Rahmawati ${ }^{2 *}$ \\ ${ }^{1}$ Program Studi Nautika, Politeknik Bumi Akpelni \\ ${ }^{2}$ Program Studi KPN, Politeknik Bumi Akpelni Semarang \\ Jl. Pawiyatan Luhur II/17, Bendan Dhuwur Semarang \\ Email: haryani@akpelni.ac.id
}

\begin{abstract}
Abstrak
Tujuan dari penelitian ini adalah untuk menganalisa dan mendeskripsikan tentang bagaimana seorang penerjemah Indonesia mengartikan makna number dan gender seperti yang dianjurkan oleh Mona Baker. Disamping itu, metode deskriptif qualitatif dan content analysis telah digunakan dalam menganalisa data, dan diambil hanya sebesar 20\% dari keseluruhan objek yang dikaji. Hasil penelitian yang diperoleh adalah: 1). Penggunaan number dengan kategori SS adalah sebesar 917 (61\%); sedangkan kategori PS dan PP hampir memiliki nilai yang sama, yaitu 314 (21\%) dan 264 (17\%); namun untuk kategori SP adalah hanya 22 (1\%); 2). Penggunaan Gender notion di GN adalah sebesar 248 (55\%), dan NG adalah sebesar 207 (45\%); 3). Oleh karena itu, dapat disimpulkan bahwa penerjemah telah berhasil melakukan penerjemahan terhadap teks tersebut dalam notion Number dan Gender di dalam novelnya.

Kata kunci: Novel, Translation, Grammar, dan Number, dan Gender
\end{abstract}

\section{BACKGROUND OF THE STUDY \\ Translation is the activity of transferring a message from one language} to another language. Therefore, this activity can be certainly involved in at least two languages; they are source language in one side, and target language in another one. Translation, according to Nida (1984) consists in reproducing in the receptor language the closest natural equivalent of the source language message, first in terms of meaning and secondly in terms of style.

On the other hand, the research from this study is discussing about a translation text in the novel of Margaret Gilbert from grammatical equivalence perspective. In another word, this study is concerned about the analyses of an English - Indonesian text by seeing the use of Number and Gender notion in the novel.

Grammatical equivalence is one of the equivalences which are proposed by Baker (1992:5). Among of them are: 1) equivalence at word level, 2) equivalence above word level, 3) textual equivalence, and 4) pragmatic equivalence. Moreover, like mention before, this particular study concerns with "Grammatical Equivalence" and its five categories that commonly lead to difficulties in finding the equivalence of meaning, they are; Number, Gender, Person, Tense \& Aspect and Voice.

In doing a good translation from one language to another language, the translators also have to consider about the "meaning". Some experts in translation field said that the meaning is very essential in transferring the message from one language to another one. This is also stated by Catford (1965:35) that meaning is very important in translation.

From the above phenomenon, a good understanding about grammatical system in source language and target language become an important thing to be considered, in order to make the translation of literary work has a good quality and can be responsible.

The research tittle about "The Analyses of Grammatical Aspect of Number \& Gender from English into Indonesian Novel Translated By Silamurti Nugroho" is very important to be conducted in terms of continuing the previous research that related with grammatical system in translation point of 
view. The study of translation in the novel of "Eat, Pray and Love" had been done by using Grammatical Equivalence approach, especially by discussing a unit of notion like Number and Gender.

\section{LITERATURE REVIEW Definition of Translation}

Schaffiner in Mona Baker
$(2001: 3)$ states that translation is
conceived primarily as a process of intercultural communication, whose end product is a text which is capable of functioning appropriately in specific situations and contexts of use. What makes translation complicated, then, is the diversity or the lack of one - to - one correlation between form and meaning, considering the fact that each languages has its own distinctive forms for representing the meaning.

$$
\text { Nida \& Taber (1974:14), }
$$

therefore explains that " Translation consist of reproducing in the receptor language the closest natural equivalence of the source language message, first in terms of meaning and secondly in terms of style". However, Bell (1991:5) has different opinion about translation that "Translation is the expression in another language (target language) of what has been expressed in another, source language, preserving semantic or stylistic equivalences". According to this definition, translation is transferring a meaning or thinking from a certain language to another one, which also must maintain the semantic and its style.

\section{Grammatical Equivalence}

To make the translation result become equal, accurate, clear, and natural, there are many aspects should be considered. One of them is grammatical equivalence. Besides that, a translator also must consider the grammatical equivalence, while he / she is doing translation from source language into target language. This is happened because the grammatical system of both English and Indonesian language has its characteristic and its own distinction, which determine reporting the experience. Based on the research conducted, there many different notions which influence the use of meaning in translation result. The notion of number has its own category to be considered, such as the use of; Singular to Singular (SS), Singular to Plural (SP), Plural to Singular (PS), and also Plural to Plural (PP). Moreover, the notion of gender which focused on masculine and feminine also has its own category like; Gender to Neutral (GN) and Neutral to Gender (NG). GN refers to using the category of notion and tends to be Gender Based, while NG refers to using Non-Gender Based.

\section{Category of Number}

Category of number is the first grammatical category which is going to be found out by the researcher, and it is becoming one of categories in English and Indonesian translation. This category includes two basic dimensions like morphology and syntax. Moreover, Mona Baker in her book said that; Grammar is organized along two main dimensions: morphology and syntax. Morphology covers the structure of words, the way in which the form of a word changes to indicate specific contrasts in the grammatical system. For instance, most nouns in English have two forms, a singular form and a plural form: man/men, child/children, car/cars. English can therefore be said to have a grammatical category of number.

However, not all languages have a grammatical category of number, and those that do not necessarily view countability in the same term. As explained above, English recognizes a distinction between one and more than one (singular and plural). This distinction has to be expressed morphologically, by adding a suffix to a noun or by changing its form in some other way to indicate whether it refers to one or more than one: student/students, fox/foxes, et cetera. 
From the above discussion, Noun is the basic part of speech that can be included in Number Category which is going to be elaborated in this study. The popular definition of a noun is that it 'describes a person, place or thing'. In fact, noun is used to express a range of additional meanings such as concepts, qualities, organizations, communities, sensations and events. Nouns convey a substantial proportion of the information in most text. A small proportion of nouns have identifiable 'noun endings'. These include: tradition, ability, instrument, excellence, significance. Many plural nouns end in s, e.g. cats.

Moreover, there are four kinds of nouns in English: 1). Common nouns, 2). Proper nouns, 3). Abstract nouns, 4). Collective nouns. A noun can function as: the subject of a verb (e.g. Cats kill Mice), act as the object of a verb (e.g. Cats kill Mice), and act as the object of preposition (e.g. I spoke to Tom), act as the complement of a verb (they are men). They often end a phrase which begins with an article such as a (n), or a quantifier such as either, any, or many. They also follow adjectives. (E.g. A drunk, either way, a much older elite, large mice, etcetera.).

On the other hand, A.J. Thomson

and A.V. Martinet classified the characteristic of nouns as follows:

1). Plurals

The plural of a noun is usually made by adding $\mathbf{s}$ to the singular: $\operatorname{Dog}-\operatorname{dog} s$, day - days, house - houses.

2). Nouns ending in o or ss, $\mathbf{s h}, \mathbf{c h}$, or $\mathbf{x}$.

Nouns ending in o or ss, sh, ch, or $\mathrm{x}$ form their plural by adding es:

Tomato - tomatoes, kiss - kisses, brush - brushes, watch - watches, box boxes.

3) Nouns ending in $\mathbf{y}$.

Nouns ending in $y$ following a consonant form their plural by dropping the $\mathbf{y}$ and adding ies:

Baby - Babies. Lady - Ladies.

Country - Countries. Fly - Flies.

However, nouns ending in $\mathbf{y}$ following a vowel form their plural by adding $\mathbf{s}$ only:

Donkey - donkeys, boy - boys day - days.

4). Twelve nouns ending in $\mathrm{f}$ or fe.

Twelve nouns ending in $\mathbf{f}$ or fe drop the f or fe and add ves. These nouns are; wife, life, knife, wolf, self, calf, shelf, leaf, loaf, thief, sheaf, half. (Example: wife - wives, knife - knives, and soon.

5). A few nouns form their plural by a vowel change.

The examples of these nouns are:

Man - men, louse - lice, foot - feet, mouse - mice, woman - women, goose - geese, tooth - teeth, ox - oxen, child - children.

6). Names of certain creatures do not change in the plural.

The example of this noun is from the word of fish. The word of fish is normally unchanged. Fishes exists but is uncommon.

7). A few other words don't change.

Aircraft, craft (boat / boats)

Quid counsel

However, there are some words always plural: police, clothes, garments. Garments which consist of two parts: pyjamas, trousers, breeches, pants etc. Besides, there are also tools or instruments consisting of two parts: glasses, spectacles, pliers, shears, scissors, scales; premises and quarters (used to mean accommodation).

From the characteristic of plural noun above, the researcher can decide the classification of number in four categories, in order to ease her in doing analysis from both of source text and target text. Those are category of SS, SP, PS, and SP. The category of SS is derived from singular to singular word. The researcher is categorizing the noun (it can be place, thing, and person) based on whether the noun itself is singular and translated into singular too (singular singular). SP means categorizing the noun based on whether the source language is singular and translates it into plural in 
target language (singular - plural). PS means the source language is plural and translate it into singular (plural singular), and SP means the translator translate the singular noun in source language become plural meaning in target language (singular - plural).

Therefore, those four categories (SS, SP, PS, and PS) are the main categories in number which helps the researcher classifying the data and answering the question in chapter 1 about "how category of number translated from English into Indonesian in is eat, pray, and love in the novel of Margaret Gilbert".

\section{Category of Gender}

Category of Gender is the second category from the notion of grammatical equivalence which had been discussed by Mona Baker in her book. Gender is a grammatical distinction according to which a noun or pronoun is classified as either masculine or feminine in some languages. The distinction applies to nouns which refer to animate beings as well as those which refer to inanimate objects.

Here it can be seen that Masculine: men, boys, and male animals (pronoun he/they), Feminine: women, girls, and female animals (pronoun she/they), Neuter: inanimate thing, animals whose sex we don't know and sometimes babies whose sex we don't know (pronoun it/they). Besides, there are also exceptions, like ships are considered feminine and sometimes cars and other vehicles when regarded with affection or respect. Countries when referred to by name are also normally considered feminine.

English does not have a grammatical category of gender such as; English nouns are not regularly inflected to distinguish between feminine and masculine. The gender distinction nevertheless exists in some semantic areas and in the person system. Different nouns are sometimes referring to female and male members of the same species: cow/bull, sow/boar, doe/stag, mare/stallion, and ewe/ram. A small number of nouns which refer to professions have masculine and feminine forms, with the suffix - ess indicating feminine gender.

From the classification and the characteristic of gender above, the researcher can differentiate the use of number in two categories, in order to ease her in doing analysis from both of source text and target text. Those are: category of Gender Based (GN) and category of NonGender Based (NG). The category of GN means that whether the Indonesian novel translator translates the noun meaning (masculine or feminine) in source language into neutral or inanimate meaning in target language. However, the term of NG means that whether the translator transfer of noun meaning in source language in the form of neutral into gender meaning.

Therefore, those two categories (GN and NG) are the main categories in gender which helps the researcher classifying the data and answering the question in chapter 1 about "how is category of gender translated from English into Indonesian in eat, pray, and love in the novel of Margaret Gilbert".

\section{METHOD}

Based on the problems discussed in the study, therefore the form of research used was a descriptive research, which aimed to describe systematically a situation or something factual and accurate. This is also stated by Issac and Michael (1984:42), "Descriptive method: to describe systematically a situation or area of interest factually and accurately.

Besides deciding the form of the research, an approach in conducting the research is also need to be considered by the researcher. The name of the approach is a descriptive qualitative. The approach had been chosen because it can get much qualitative information carefully and accurately. Therefore, this should be done 
because the data that appeared in the study is mainly about words, instead of numbers. As stated by Miles and Huberman (1984:21), “..........what, in short, do we consider qualitative analysis to consist of? First, the data concerned appear in words rather than in number.

Moreover, the research data which was analyzed in this research was about the use of grammatical categories and its notions like: Number and Gender. However, based on the data scope, the researcher used the data sampling and limited the analyzing only 21 chapters.

Sutopo (2002:54) explains that sampling is related with the limitation of number and types of source data which will be used in a research. However, the notion of this statement cannot be avoided by the researcher in doing her research, because there is a limitation of time, power, cost, and et cetera in doing the research.

Considering to the limitation of the time $\&$ based on the source of data above, therefore the data which had been analyzed was only $20 \%$ from 108 chapters within 348 pages. In other words, the amount of data as the sampling was only 21 chapters with 67 pages in English novel version, and 76 pages in Indonesian novel version.

\section{RESULT AND DISCUSSION}

The Analyses of Grammatical Aspect of Number Translated from English into Indonesian.

Based on the classification of notion about number in Mona Baker (1992), there are 1517 kinds of data about singular \& plural form found in the novel text. As explained earlier, English recognizes a distinction between one and more than one (singular and plural). The distinction has to be expressed morphologically, by adding a suffix to a noun or by changing its form in some other way to indicate whether it refers to one or more than one.
From the distinction above, the researcher had formulated the number category based on its changing in meaning, like; singular to singular (SS), singular to plural (SP), plural to plural (PP), and the last is plural to singular (PS). However, the fourth number categories have its own meaning when transferring the message into TT. As the example found in the text, the word of "a woman" and "seorang wanita" were translated by the translator and included into SS category, "a dogmatic scripture" and "injil-injil dogmatis" were translated and included into SP category , "the words" and "kata-kata" were translated and included into PP category, "countries" and "Negara" were translated and included become PS category.

\section{The analysis of Transferring Meaning} from Singular to Singular (SS).

There are 917 singular data from noun or pronoun in source language text which transfer into receptor language and in the form of singular too. The meaning itself did not have any distortion or addition meaning, because the translator transfers the meaning lexically.

In addition to using the singular meaning in ST, the data were usually used: 1) an article $\mathbf{a}$ or $\mathbf{a n}, 2)$. The changes of the vowel sound like " $\mathrm{f}$ " sound change into "v" sound, 3). The use of noun which ended by "ance or ence", 4). The use of noun which ended by "tion", 5). The use of "man" \& "child", 6). The use of noun without using "s" or "es" at the end of the word.

Moreover, there are 917 of data using category of SS from the English text (ST) and translated them into Indonesian (TT).

The analysis of Transferring Meaning from Singular to Plural (SP).

There are only 22 data used singular to plural. This category was the smallest one if it was compared into SS, PS, and PP. The data from noun or pronoun in source language text was singular and transferred it into receptor 
language in the form of plural. The meaning in TT had any addition meaning or even repetition which indicated had more than one meaning.

In another hand, the use of singular meaning in ST could be seen through the use of article "a" and "an", and also there was no additional letter like "s" and "es" at the end of the word. However, the use of repetition words in TT indicated that the meaning was plural.

Besides of the description above, the use of noun in ST which indicated plural meaning was by borrowing $\begin{array}{llll}0036 & 0144 & 0147 & 0262\end{array}$ $\begin{array}{llll}0700 & 0708 & 0885 & 0913\end{array}$ $\begin{array}{llll}1263 & 1304 & 1304 & 1309 .\end{array}$

Besides categorizing of the SP data above, the researcher provided comment on each word which had been listed likewise on the attachment table. The comments that indicated to SP category are like:

- The meaning in ST is singular, but the meaning is changed become plural in TT.

- The existence of word "umat" in TT makes the meaning become plural.

- The meaning in TT is changed become plural, because there is a repetition of word "injil-injil".

- The use an article "a" in ST and the repetition of word "saat-saat" in TT make the meaning is changed become plural.

- The meaning in TT is plural because there is word "para' which means more than one reader.

\section{The analysis of Transferring Meaning} from Plural to Plural (PP).

There were 314 data used plural to plural. This category (PP) was bigger in number than plural to singular (PS) category. The data from noun or pronoun in source language text is plural and transfer it into receptor language in the form of plural too. The meaning in TT did not have any distortion or even addition meaning. The characteristic of using plural meaning in ST was by having quantifier like few, and so on. Some of the words that already translated into TT were like appearing of prefix: "beberapa, umat, para" in target language.

In addition to seeing the above two example of SP category, there were only 22 of data using category of SP from the English text (ST) and translated them into Indonesian (TT). The sentence number also might have more than one "singular" word, and the list of using the number SP category had been analyzed and can be seen from these following sentences number:

$\begin{array}{lllll}0404 & 0509 & 0520 & 0645 & 0672 \\ 0985 & 1028 & 1119 & 1152 & 1189\end{array}$

quantifier (many, few \& a few) in the front of the word, and also using prefix "s" or "es" in noun or pronoun, and also using cardinal number like 1,2,3 and et cetera. However, the use of plural meaning in TT was by having additional words like: "semua, beberapa, para, kaum, umat".

\section{The analysis of Transferring Meaning} from Plural to Singular (PS).

There were 264 data used plural to singular. This category (PS) was bigger in number than singular to plural (SP) category. The data from noun or pronoun in source language text is plural and transfer it into receptor language in the form of singular. The characteristic of plural words in ST is by having " $\mathrm{s}$ " or "es" at the end of the words, but when it translated into TT, the meaning become singular, because there was no addition of word "beberapa, para, or semua" in TT. The list of the words that used PS category was as follows:

Furthermore, based on the fourth category of SS, SP, PS, and PP explained above, it can be concluded that from 1517 data in the form of sentences that used in Singular-Singular (SS) form is 917 or 61 $\%$, and in Singular - Plural (SP) form is only 22 or $1 \%$, however, in Plural - Plural (PP) form is 314 or $21 \%$, and the last is in Plural - Singular (PS) form is 264 or 17 $\%$. To make the data is easier to be read, 
the researcher put it in the form of tabulation table below:

Table 1: The Tabulation of Using Number Category.

\begin{tabular}{clccc}
\hline No & $\begin{array}{c}\text { Classifications of } \\
\text { Numbers }\end{array}$ & Code & Freq & Percentage \\
\hline $\mathbf{1}$ & Singular to Singular & SS & 917 & $61 \%$ \\
$\mathbf{2}$ & Singular to Plural & SP & 22 & $1 \%$ \\
$\mathbf{3}$ & Plural to Plural & PP & 314 & $21 \%$ \\
$\mathbf{4}$ & Plural to Singular & PS & 264 & $17 \%$ \\
& $\quad$ Total & & $\mathbf{1 5 1 7}$ & $\mathbf{1 0 0 \%}$ \\
\hline
\end{tabular}

From the above table, it could be seen that the biggest numbers which mostly found in the novel is Singular Singular (SS) $61 \%$, follow successively by Plural - Plural (PP) $21 \%$, and Plural Singular (PS) $17 \%$. However, Singular Plural was the smallest one, only $1 \%$.

\section{The Analyses of Grammatical Aspect of Gender Translated from English into Indonesian.}

Gender can be in the form of masculine or feminine or even neutral. This is also proposed by Mona Baker, 1997:90-91 in her book that "Gender is a grammatical distinction according to which a noun or pronoun is classified as either masculine or feminine in some languages". From the data found, sometimes a gender type can be translated into neutral or vice versa. The use of possessive adjective and possessive pronoun in ST, the doer can be masculine or feminine.

The Analyses of Gender Based (GN).

The analyses of gender based means when the noun or pronoun in ST was indicated masculine or feminine, but the meaning in TT was changed become neutral. This was happened while transferring into target language (TT), the meaning became neutral, because the use of words "nya" and "dia".

Moreover, based on the data found, there are 248 (55\%) data uses gender based. To elaborate the findings, it is necessary to list down the number of sentences which indicated and represented to $\mathrm{GN}$.

\section{The Analyses of Non-Gender Based} (NG).

The analysis of non-gender based referred to noun or pronoun which did not have masculine or feminine meaning, both in source text language or target text one.

From the data found, there were 193 data or $42 \%$ data which indicated to be non-gender based. Moreover, these following examples were indicating the use of NG from the data found in the novel text.

In addition to listing the data above, here is the tabulation of data which was referring to Gender Based, and Non Gender Based. The table can be seen as follows:

Table 2: The tabulation of using Gender Category.

\begin{tabular}{lcc}
\hline & Gender Based & Non-Gender Based \\
\hline Total of Frequency: & 262 & 193 \\
Percentage: & $\mathbf{5 8} \%$ & $\mathbf{4 2} \%$ \\
\hline
\end{tabular}




\section{CONCLUSION}

This study reported the result of how is grammatical of Number and Gender used and translated from English into Indonesian in the novel of Margaret Gilbert. The purpose of this research was to discover how far was the Indonesian translator translate the meaning of Number and Gender under the theory of Mona Baker in accordance with the grammatical equivalence.

From the result of the analyzing, it could be described that the use of number as the first category in grammatical equivalence was about 1517 data. The number of data itself was also breaking down into four categories which had their own value, such as SS was 917 data (61\%), PS was about 314 data (21\%), and the next continued by PP was about 264 data (17\%), and the last was SP about 22 data $(1 \%)$.

In addition, the data that indicated to Gender Based (GN) was bigger than data of Non-Gender Based (NG). The use of noun or pronoun in ST was referring to masculine or feminine, or even neutral. The use of meaning in Gender and translated it into Neutral was about 248 data (55\%) from the whole data. However, the use of meaning in Neutral and translated it into Gender was about 207 (45\%). In another words, the use of GN was bigger than NG.

From the above explanation, it could be concluded that the translator had been successfully translated the text, especially in transferring the meaning of Number and Gender into the target language.

\section{REFERENCES}

Baker, M. 1992. In other words: A course book for Translation. London: Routledge Bell, R.T. 1991. Translation and Translating, Theory and Practice. London: Longman
Catford, J.C. 1965. A linguistic Theory of Translation. London: Oxford University Press

Gilbert E. 2006. Eat, Pray, and Love. Jakarta. Abdi Tandur

Issac, Stephen and William B. Michael. 1984. Handbook in Research and Evaluation. San Diego: Edits Publisher.

Hatim, Basil and Ian Mason. 1990. Discourse and the Translator. New York: Longman Inc

Hatim, B.2001. Teaching and researching Translation. Britain: licensing Agency Ltd.

Larson, L.M. 1984. Meaning Based Translation, A guide to cross language, Equivalence. Lanham: University Press of America

Martinet, Martthiessen \& Painter. 1997. Working with functional grammar. London: Great Britain.

Nida, E.S. 1974. Translation and Translating. Theory and Practice. Leiden: E.J Brill

Nababan, M.R. 2003. Teori Penerjemahan Bahasa Inggris. Yokyakarta: Pustaka Pelajar.

Swan, Michael. 1988. Practical English Usage. Oxford University Press

Sutopo, H. B. 2002. Metodologi Penelitian Kualitatif. Surakarta: Sebelas Maret University Press

Schaffner, C. Translation Research and Interpreting Research. Great Britain: the Cromwell Press Ltd 